\title{
PRAGMATIC COMPETENCE OF TEACHER-STUDENTS AT ENGLISH EDUCATION DEPARTMENT
}

\author{
Nunung Nurjati ${ }^{1)}$, Ferra Dian Andanty ${ }^{2)}$ \\ ${ }^{1,2}$ English Education Department, University of PGRI Adi Buana Surabaya \\ email: nunung.nurjati@gmail.com ${ }^{1)}$, ferradian@ gmail.com ${ }^{2)}$
}

\begin{abstract}
English in Indonesia is still acting as a foreign language in a way that the language is still limited in use to be practiced in schools. English has not been as a second language in Indonesia. As a foreign language, English is still not fully utilized as appropriate in countries native speakers. The L2 still encounter verbal interaction with speakers of foreign languages, especially English teachers and learners in schools that are not in accordance with the function and the situation. The purposes of this study are to (1) describe the utterances used by the lecturer-student in meaningful situation, and (2) to describe a form of speech which implies related to the competence of pragmatic form of representation of (1) deixis, (2) conversational implicatures, (3) pre-supposition, and (4) acts of speech in the discourse of learning instructional interaction in English language education courses. This study uses a qualitative approach to the narrative definition. The data of this study include: (1) verbal aspects of speech acts between lecturer and students situational context, and (2) a form of speech acts that implies in terms of illocutionary and in terms of conversational implicatures.
\end{abstract}

Keywords: pragmatic competence, situational meaning, narrative definition, deixis, conversational implicatures

\section{INTRODUCTION}

English in Indonesia is still acting as a foreign language, the language used is still limited in practice in schools. English has not been considered as a second language in Indonesia. As a foreign language, English is still not fully utilized as appropriate in countries native speakers. Therefore still frequently encountered verbal interaction speakers of foreign languages, especially English teachers and learners in schools that are not in accordance with the function and the situation. One language skills that can facilitate access to knowledge is pragmatic competence, i.e competence that focuses on the use of language both orally and in writing. If second language (L2) learners acquire pragmatic competence, they easier to understand a discourse or knowledge are delivered orally. In everyday life, the use of language is not solely based on the principle of well-formed in syntax, but rather on the basis of interests so that communication can still run smoothly. In more precise, the language used by a speech community as a way of mutual interaction of the participants understand what they utter. On this basis, first, it is understood, and it is often found that communication can be conducted despite using a language that is not slick syntactically. Secondly, for the needs of the speech community members to organize and understand their activities, in addition to grammar, the meaning is also the case that cannot be ignored in the analysis of language. Thus, it is understood that the main difference between syntax and pragmatics, as well as stating the importance of pragmatic studies in linguistics, lies in the meaning of the speech and the language users.

\section{THEORETICAL FRAMEWORK}

In language teaching, as expressed by Gunarwan (2004: 22) (in Quinz 2008) there is a link, namely that the pragmatic knowledge, in a practical sense, it should be known by teachers to equip learners with the knowledge about the use of language in certain situations. In the Indonesian language teaching, for example, this knowledge is essential to guide the learners to be able to use a variety of language that is appropriate to the situation, because in addition to the real situation, 
the language used should be good. As quoted by Kridalaksana (2007: 3) that language is a sound alert system approved for use by the members of certain communities to collaborate, to communicate and to identify among them. From that sense it can be described that language is a system of systematic, meaning that the language can be described on limited units that combined with rules that can be foreseen. In addition, the language is also systemic not just a single system, it consists of several subsystems, i.e subsystems phonology, grammar and lexicon. The subsystem within the world of sound and meaning of the world meet, thus forming a structure in which there is a context. Context affects the compatibility of the system of a language. As disclosed in the book Enchantment Kushartanti Language Understanding the Early Steps Linguistics (2007: 104) is an element outside the context of the language, studied in pragmatics.

For the latest level in linguistics, pragmatics is the level is in a way that it takes into account the human as language users. Wijaya (1996: 1) states, in contrast to phonology, morphology, syntax and semantics are studying the internal structure of the language, pragmatics is the branch of linguistics that studies the structure of external language, that is how it is used in a unit of linguistic communication. Morris (Rustono 1999: 1) as the originator of the first field of this study revealed that pragmatics is the branch of semiotics that studies the relation of signs and interpretation. In structural linguistics analysis, the discussion is stressed on the structure, or formal form of language. A sentence is analyzed by observing the subject and predicate in a sentence which forms part of the subject can be sorted out again into parts smaller, as well as the predicate. And the parts can still be sorted further and passed down to the smallest such a clause, phrase, word, morpheme, even phonemes. In the analysis, the context of the use of the phrase was not taken into account.

The scope of pragmatics is a separate field in linguistics, which is described as (1) deixis, (2) conversational implicatures, (3) presuppositions, and (4) speech acts. Deixis is a symptom of semantics contained in words or constructions that can only be interpreted by considering the context of the conversation benchmark. In other words, the words saya (I) or, sini (here), sekarang (now), for example, has no reference to a fixed but varies depending on a variety of things. A reference from my words became clear after a known who is saying it. The word here has a real reference as to know where the word was spoken. Similarly, the word now when it is also known that word when is uttered. Thus the words above include deixis' words, unlike the case with words such as tables, chairs, cars, and computers. Anyone who says, wherever, and whenever, these words have a clear reference and fixed. Deixis can be grouped into five categories; persona, place, time, discourse, and social (Levinson in Nadar, 2009:53). Conversational implicature is one of the most important ideas in pragmatics. Implicature conversation is basically an inferential nature theory, a theory about how people use language, the meaning of a speech that the relationship was not revealed literally in the speech. Brown explains, "Implicature means what a speaker can imply, suggest, or mean, as distinct from what the speaker says literally".

Conversational implicatures means what is implied, suggested, or intended by the speaker literally unspeakable in the utterances. According to Levinson (by Nadar, 2009: 61), mentions that implicature as one of the most important ideas or thoughts in a pragmatics. One important reason he gives is that implicatures provide some explicit account of how it is possible to mean more than what is actually said.

Example:

Risa : "Can you tell me the time?

Sandra : "Well, the milkman has come".

The answers to questions do not seem relevant to Risa request on time, but Sandra is simply saying that the person concerned does not know exactly what time at that moment. She hopes the questioner can guess the time by herself by saying that the milkman has come. In this context, it seems speakers and opponents alike said already, knowing that at usual time the milkman comes. 
If a sentence is spoken, apart from the meaning expressed by the sentence pronunciation, joined participate also additional meaning that is not stated but implied from the pronunciation of words. This sense is the presupposition. Spoken sentence can be considered irrelevant or wrong not only because incorrect disclosure but also because its presupposition is wrong. Example:

\section{A: What about inviting John tonight?}

$B$ : What a good idea; then he can give Monica a lift

Presuppositions contained in the above conversation, among others: (1) That the A and B are familiar with John and Monica, (2) that John has a vehicle - most likely a car, and (3) that Monica does not have a current vehicle.

Speech acts according to Austin is to say something is doing something. Austin specifically argued that the speech-speech does not merely want to communicate some information, but asking for an act or acts. Example:

When someone says, for example: "I'm sorry"; "I promise"; that is to say, the apology made by the time the person apologizing instead of before. Promise or later arrival must be met, and instead now. In analyzing the speech acts or utterances is the study about the effects on behavior speech of the speaker and interlocutor. Austin distinguishes three types of effects follow utterances, namely: a locution acts, illocutionary acts, and perlocutionary acts. Locution acts refer to the literal meaning, the basic meaning, or meanings referential contained in speech. Actions taken as a result of a speech called illocutionary acts. In this case, illocutionary acts meaning "to say is to do". Perlocutionary acts refer to the effect or influence of a speech to the speaker or the hearer.

Crystal in Kasper (1997) states that pragmatics is a study of language from the perspective of the language itself, in particular about the choice of words that they use. On the other hand, it was also found that pragmatic emphasis on how the arrangement of words or phrases that can change the meaning of a sentence or utterance. Speech uttered by the user language when he speaks tends to be ambiguous. That means that their speech may mean / other meanings besides of its true meaning. Therefore, to understand and know the intent of the person who speaks it, who is speaking, and the context of those talks is essential in order to facilitate the interlocutor understand the meaning of words that conveyed so there are no misunderstandings and the response given will also be appropriate. So, with know and understand the intent of the speaker, the language will be easy to share knowledge and information. They will also be able to achieve the main goal of communication is to convey to each other and receive information. From the above explanation, one language skills can facilitate students in transferring knowledge and information is the competence of pragmatic. According to Brown (2007), the pragmatic competence is the ability to produce and understand sociolinguistic and also functional aspects of language. Actually, pragmatic competence itself emphasizes the use of spoken language and writing. However, this study only focuses on the use of verbal language that is where the emphasis on speaking. There are several things that must be considered in speaking such, the context, the intention of the speaker, culture and also in terms of grammar/structure. Talking is a tool that is pending in communication, thinking, and learning. Chaney in Kayi (2006) defines that talking is a process in building and sharing of information through the use of symbols either verbally or non-verbally in a variety of contexts. Through speaking, students are not only able to express ideas, feelings, and themselves verbally but also can learn how to follow and understand the rules of social and cultural appropriately in every situation. In this regard, effective learning is needed by the students. Automatically, it will also affect their pragmatic competence. According to Kasper (1997), the pragmatic competence should be developed by the students to be able to communicate well. In developing pragmatic competence of students, course students should be given plenty of time to practice speaks any of them. Coulman in Kasper (1997) also argues that students must take turns in speaking in various situations. In other words, it needed an effective exercise which involves interaction centered on students. Porter in Lee and VanPatten (2003) found that the 
interaction between the students in the classroom results in an increase in the student the opportunity to express by themselves. Therefore, learning to speak in schools should engage students in effective interaction so that they are not only able to speak but also able to understand what the intent of the speaker and are also able to use a proper greeting. In other words, students should have a pragmatic competence, especially with regard to pronunciation, grammar, vocabulary, fluency and comprehension.

There are several previous studies that examined about pragmatic competence. One of them is a fairly new research conducted by IGA Lokita Purnamika Utami which examines how to develop pragmatic competence for high school students in Singaraja. Utami (2000) in his research to develop the competence of pragmatic subjects of the study through an intervention with a variety of learning techniques speech (speaking) in English, namely: Role Play, Group Story Telling and Fun Games, Panauricon, and Guided Dialogue to figure out which techniques are most effectively to improve student learning outcomes.

\section{RESEARCH METHODOLOGY}

The research design of the study uses a qualitative approach to the design of pragmatic perspective to determine the pragmatic competence. Through the perspective of pragmatics (Levinson, 1983; Leech, 1993; Cumming, 2007) can be analyzed variety of speech acts used a lecturer in interaction in learning with students in the classroom who represent that (1) deixis, (2) conversational implicatures, (3) presupposition, and (4) speech acts that were described during the study period with the subject of the research that has been determined.

Data from this study are in the form of verbal utterances aspect of lecturers and students of English language education in instructional discourse in learning in the classroom. The data source of this research is the discourse of instructional learning courses of Speaking in English Language Study Program PGRI Adi Buana University Surabaya arising from the interaction of communications lecturer and students in the classroom.
Data collection techniques used in this study is to consider the method and technique of recording (Sudaryanto, 1993) and the observation techniques nonparticipation (Kuswarno, 2008). Refer to the method and the recording technique used to collect data in the form of verbal aspects of speech if the lecturer and students in instructional interactions, whereas the observation techniques used to obtain data supporting the form of field notes on aspects of speech. Technique of data analysis in this research is descriptive which utterances are grouped in classification (1) deixis, (2) conversational implicatures, (3) pre-supposition, and (4) acts of speech.

In the early stages of research things to be prepared is the perception among researchers and lecturer of the course of content subject of Speaking. Because the source of the data from this study is in the form of discourse instructional learning of the Speaking subject on the Study Program English Education University of PGRI Adi Buana Surabaya which is arising from the interaction of communications of lecturer and students in the classroom, then the data retrieval must record the interactions that occur in the form of audio and visual. Make the perception by lecturer of the course of content subject Speaking necessary so that the interaction that occurs in the classroom is delivered naturally. When the interaction occurs naturally, the data obtained can be analyzed in accordance with the rules of the theoretical background of this study.

Research data retrieval adjusts to schedule regular lecture courses intended. Early college semester 2014/2015 academic year begins in early March 2015. Generally, the initial lecture filled with lectures contract so that retrieval of data by recording the lecturer-students interaction is done at the third meeting. The recording lasts until the end of the lecture. Recording lecturer-students interaction in the classroom instructional discourse ends in mid June 2015. But of all the recording is not all the data collected can be used as the data are analyzed as some recording does not produce data as expected. Recording results like this are discarded because the data collected cannot be used. 


\section{FINDINGS AND DISCUSSION}

Before analyzing the data, some steps done is to sort out the conversation between the lecturers and students that fall into the category of deixis, conversational implicature, presuppositions, and containing speech acts. From the interactions which were recorded, much of the data could not be used because they did not meet the criteria as intended in the four categories has been mentioned above. This is because the recorded interaction is the interaction that generally occurs between lecturer and students in the classroom learning. So that can be analyzed only a few pairs of conversations that contain the four categories above. The analysis was performed on recordings on the subjects which have been transcribed. The first results are visible after the categorization of each on deixis, conversational implicature, pre-supposition, and speech acts.

After completion of the experiment and the analysis have been done, the findings revealed that there were no striking differences among the language groups in regard to the utterances which addressing certain conditions to the experiment, so such utterances will eliminate in frequency. It was noted from the experiment that utterances commonly consist of positive and negative declarative intonations. Negative declarative seems to be more polite than semantically positive question forms. The explanation for this seems to be that they are being used to confirm a speaker presupposition that the addressee does not have the desired thing and therefore provide the addressee with a built-in excuse for rejecting request. Further, native speakers of second language usually do not use declarative intonation questions. So, learners were transferring their native language speech act strategies and avoid commonly used intonation pattern.

\section{CONCLUSIONS}

There is significant conclusion to be drawn from the study. The study have indicated that learners learn pragmatic competence more effectively on the complex speech acts and develop their pragmatic competence more effectively when they receive instruction on the speech acts and responses. However, the effect differs according to the type of tasks in which students participate, and in accordance with the rigor of instruction and feedback.

The results of this study suggest several implication for the teaching speaking skills particularly that of pragmatic competence. It becomes clear that teachers need to focus their efforts actively not only on teaching contrasting linguistic structure in English as the second language, but also on how to make the correct sociopragmatic choices in conversation. In realizing that purpose, the class of second language learning should facilitate learners' successful interactions with native speakers.

\section{REFERENCES}

Austin, John L. 1962. How to Do Things with Word (edisi kedua). Oxford: Oxfod University Press.

Brown, Penelope., dan Stephen C. Levinson. 1978. Politeness: Some Universal in Language Usage. Cambridge: Cambridge University Press.

Cross, D. 1991. A Practical Handbook of Language Teaching. London: Cassel

Eelen, Gino. 2001. A Critique of Politeness Theories. Manchester, UK: St. Jerome Publishing

Gunarwan, Asim. 2004. Dari Pragmatik ke Pengajaran Bahasa (Makalah Seminar Bahasa dan Sastra Indonesia dan Daerah). IKIP Singaraja.

Jaszczolt, K.M. 2002. Semantics and Pragmatics: Meaning in Language and Discourse. Edinburgh: Pearson Education.

Koike, A. D., \& Pearson, L. The effect of instruction and feedback in the development of pragmatic competence. System 33 (2005) 481$501 \quad$ www.sciencedirect.com. Accessed 24 October 2015

Kushartanti. 2007. Pesona Bahasa Langkah Awal Memahami Linguistik. Jakarta: PT Gramedia Pustaka Utama

Ladegaard, H.J. Politeness in young children's speech: context, peer group influence and pragmatic competence. Journal of Pragmatics $36 \quad$ (2004) 2003-2022 www.sciencedirect.com. Accessed 24 October 2015 
Quinz. Pragmatik Sebuah Kajian Awal. Gaudi1529.blogspot.com/2008/05/pra gmatik-sebuah-kajian-awal.html (accessed03/11/09)

Renkema, Jan. 2004. Introduction to Discourse Studies. Amsterdam: John Benjamins Publishing Company

Rustono. 1999. Pokok-Pokok Pragmatik. Semarang: CV IKIP Semarang Press

Thomas. Jenny. 1995. Meaning in Interaction: an Introduction to Pragmatics. London/New York: Longman.

Song, Sooho. 2012. Politeness and culture in second language acquisition. New York: Palgrave Macmillan
Utami, I.G.K., L., P. 2010. Pengembangan Kompetensi Pragmatik Bahasa Inggris pada Siswa SMA Negeri 1 Singaraja (http://lokitapurnamika.blogspot.com/ 2010/09/ pengembangan-kompetensipragmatik.html, diakses 20-3-2014)

Wijaya, Dewa Putu. 1996. Dasar-Dasar Pragmatik. Yogyakarta: Penerbit Andi

Yule, George. 1996. Pragmatics. Oxford. Oxford University Press 